\title{
Exercise training in the aerobic/anaerobic metabolic transition prevents glucose intolerance in alloxan-treated rats
} Clécia Soares de Alencar Mota*1, Carla Ribeiro1, Gustavo Gomes de Araújo1, Michel Barbosa de Araújo ${ }^{1}$, Fúlvia de Barros Manchado-Gobatto1, Fabrício Azevedo Voltarelli ${ }^{1}$, Camila Aparecida Machado de Oliveira ${ }^{2}$, Eliete Luciano ${ }^{1}$ and Maria Alice Rostom de Mello ${ }^{1}$

Address: ${ }^{1}$ Institute of Biosciences, Department of Physical Education, São Paulo State University, Unesp, SP, Brazil and ${ }^{2}$ Institute of Biosciences, Department of Physiology and Biophysical, Campinas State University, Unicamp, SP, Brazil

Email: Clécia Soares de Alencar Mota* - cleciamota@yahoo.com.br; Carla Ribeiro - carla_ef_rc@yahoo.com.br; Gustavo Gomes de Araújo - gusta_ef@yahoo.com.br; Michel Barbosa de Araújo - mbujo@ig.com.br; Fúlvia de Barros Manchado-

Gobatto - fbmanchado@yahoo.com.br; Fabrício Azevedo Voltarelli - faunesp8@yahoo.com.br; Camila Aparecida Machado de Oliveira - camo@rc.unesp.br; Eliete Luciano - eliete@rc.unesp.br; Maria Alice Rostom de Mello - mellomar@rc.unesp.br

* Corresponding author

Published: 2 October 2008

BMC Endocrine Disorders 2008, 8:1। doi:10.1 186/1472-6823-8-II
Received: 15 October 2007

Accepted: 2 October 2008

This article is available from: http://www.biomedcentral.com/1472-6823/8/II

(c) 2008 Mota et al; licensee BioMed Central Ltd.

This is an Open Access article distributed under the terms of the Creative Commons Attribution License (http://creativecommons.org/licenses/by/2.0), which permits unrestricted use, distribution, and reproduction in any medium, provided the original work is properly cited.

\begin{abstract}
Background: Ninety percent of cases of diabetes are of the slowly evolving non-insulin-dependent type, or Type 2 diabetes. Lack of exercise is regarded as one of the main causes of this disorder. In this study we analyzed the effects of physical exercise on glucose homeostasis in adult rats with type 2 diabetes induced by a neonatal injection of alloxan.
\end{abstract}

Methods: Female Wistar rats aged 6 days were injected with either $250 \mathrm{mg} / \mathrm{kg}$ of body weight of alloxan or citrate buffer $0.01 \mathrm{M}$ (controls). After weaning, half of the animals in each group were subjected to physical training adjusted to meet the aerobic-anaerobic metabolic transition by swimming I h/day for 5 days a week with weight overloads. The necessary overload used was set and periodically readjusted for each rat through effort tests based on the maximal lactate steady state procedure. When aged $28,60,90$, and I 20 days, the rats underwent glucose tolerance tests (GTT) and their peripheral insulin sensitivity was evaluated using the HOMA index.

Results: The area under the serum glucose curve obtained through GTT was always higher in alloxan-treated animals than in controls. A decrease in this area was observed in trained alloxantreated rats at 90 and 120 days old compared with non-trained animals. At 90 days old the trained controls showed lower HOMA indices than the non-trained controls.

Conclusion: Neonatal administration of alloxan induced a persistent glucose intolerance in all injected rats, which was successfully counteracted by physical training in the aerobic/anaerobic metabolic transition. 


\section{Background}

Diabetes mellitus is caused by the reduced secretion and/ or diminished action of insulin. Diabetic individuals fall into two distinct groups, those in which the disease is caused by a lack of insulin - known as insulin-dependent diabetes mellitus or IDDM - or by a certain resistance to the action of insulin, known as non-insulin-dependent diabetes mellitus or NIDDM.

NIDDM develops in a slow and delayed manner, and accounts for about $90 \%$ of the cases of diabetes. The main causes of type 2 diabetes include obesity, high calorie intake and a sedentary lifestyle [1].

Insulin resistance inhibits glucose consumption by muscles and adipose tissues, and stimulates glucose release by the liver, leading to hyperglycemia. There is evidence that insulin resistance may be the first derangement in cases of diabetes, preceding the onset of hyperglycemia [2].

In 1989, Portha et al. developed an experimental model for testing insulin resistance by administering streptozotocin to newly born rats. This caused transitory hyperglycemia in the rats, with basal serum glucose levels returning to normal values in the first week of their lives, after the production of insulin by $\beta$ cells normalized [3]. Later, Kodama et al. [4] described another mode of inducing insulin resistance in rats by substituting streptozotocin for alloxan [4]. In this model, alloxan was administered to Wistar rats of 2, 4, or 6 days of age. When they reached the age of 60 days, all rats that had received alloxan on their $2^{\text {nd }}$ day of life showed slightly increased non-fasting serum glucose, whereas those that had received the drug on the $4^{\text {th }}$ or $6^{\text {th }}$ day of life showed significantly higher plasma glucose levels than did the controls.

Unlike the rats treated with streptozotocin, those treated with alloxan on the $4^{\text {th }}$ or $6^{\text {th }}$ day of life showed increased longevity coupled with persistent hyperglycemia, since insulin production by pancreatic $\beta$ cells did not normalize.

In a previous study we analyzed the model developed by Kodama et al. [4] and observed that all male Wistar rats which had received alloxan $(200 \mathrm{mg} / \mathrm{kg}$ body weight $)$ at 2 days old managed to recover from the glucose intolerance on the $90^{\text {th }}$ day [5], while other metabolic disorders, such as high levels of circulating Free Fatty Acid (FFA), persisted during the experimental period.

Regular physical activity has been proved to be efficient in normalizing glucose homeostasis in diabetic patients, as well as improving insulin sensitivity and glucose tolerance [6-8]. Aerobic exercises are generally prescribed to patients with type 2 diabetes $[6,7,9]$. Since there are limitations to experimentation with humans, the use of animal models is necessary when testing these strategies.

The aim of the present study was to analyze the effects of a physical exercise programme, adjusted to the aerobicanaerobic transition, on glucose homeostasis in adult Wistar rats treated with alloxan when newly born.

\section{Methods \\ Animal treatment}

The studies were carried out using newly born female Wistar rats, kept at $25 \pm 1{ }^{\circ} \mathrm{C}$ and under a $12 / 12 \mathrm{~h}$ light-dark cycle. The animals were fed on a special purified diet for rodents prepared in our laboratory (following AIN-93G [10]) and they were allowed water ad libitum. Food and water intake as well as the body weight of all animals were recorded weekly. All animal procedures complied with the European Convention for the Protection of Vertebrate Animals used for Experimental and other Scientific Purposes of the Council of Europe, n 123, Strasbourg, 1985.

\section{Administration of alloxan}

On reaching the age of 6 days, 16 female rats were injected intraperitoneally with alloxan monohydrate (SigmaAldrich Inc., St Louis, MO, USA) dissolved in citrate buffer $0.01 \mathrm{M}, \mathrm{pH} 4.5$ to a concentration of $250 \mathrm{mg} / \mathrm{kg}$ of body weight. The animals were fasted for $16 \mathrm{~h}$ prior to drug administration [4]. Sixteen rats of the same age injected with the same volume of citrate buffer were used as controls. All the experimental procedures were carried out as originally proposed by Kodama et al [4], except that those authors injected a lower dose of alloxan $(200 \mathrm{mg} / \mathrm{kg}$ of body weight). Previous studies in our laboratory [5] showed that using alloxan $200 \mathrm{mg} / \mathrm{kg}$ of body weight resulted in spontaneous recovery from glucose intolerance in all rats after 90 days of experimentation.

\section{Experimental groups}

The animals (both controls and alloxan-treated) were randomly divided into groups of 8 after weaning (28 days), and were treated up to 120 days old as follows:

- Controls (C): no exercise programme;

- Trained Controls (TC): underwent a swimming training programme;

- Alloxan (A): no exercise programme;

- Trained Alloxan (TA): underwent a swimming training programme;

\section{Glucose tolerance test (GTT)}

All rats were fasted for $16 \mathrm{~h}$ when they reached the age of $28,60,90$, and 120 days, then a glucose solution $(200 \mathrm{~g} /$ 
L) was administered via a catheter through the mouth into the stomach at a dose of $2.0 \mathrm{~g} / \mathrm{kg}$ of body weight. Blood samples $(25 \mu \mathrm{L})$ were then taken from a cut on the tip of their tails to determine the levels of serum glucose at 0,30 , 60 , and $120 \mathrm{~min}$ after glucose administration. In addition, blood samples $(75 \mu \mathrm{L})$ were obtained at 0 min to obtain insulin levels in order to calculate the HOMA (Homeostasis Model Assessment) insulin sensitivity index.

The levels of serum glucose were determined using the glucose-oxidase colorimetric enzymatic method (Laborlab Kit, Guarulhos, São Paulo, Brazil), while levels of insulin were measured by radioimmunoassay [11]. The blood response to glucose during the GTT was evaluated based on the total area under the curve of serum glucose $(\mathrm{mM} \times$ $120 \mathrm{~min})$ [12].

\section{Sensitivity to insulin}

Peripheral insulin sensitivity was evaluated on days 28 , 60,90 , and 120 based on the HOMA insulin sensitivity index using the following equation: serum insulin (pmol/ L) $\times$ serum glucose $\mathrm{mmol} / \mathrm{L} / 22.5$. Using this method, higher HOMA indices denoted lower insulin sensitivity [13].

\section{Effort test}

On the 28th day, all animals were subjected to an effort trial to determine their individual exercise intensity necessary to reach the aerobic/anaerobic metabolic transition, following the Maximal Lactate Steady State protocol (MLSS). This protocol was designed to detect the highest blood lactate concentration at which the entrance of lactate into the blood stream was counterbalanced by its removal, maintaining a stable concentration during exercises of constant intensity [14]. This has proved useful in prescribing exercises to and determining the aerobic capacity of humans [15], rats [16] and mice [17]. Our research group has recently designed a MLSS protocol for rats using swimming exercises [18], which was employed in this study. In short, to determine the MLSS, a series of 25 min swimming exercises were performed, which supported increasing overloads in relation to body weight, and were fixed in each series, with intervals of $48 \mathrm{~h}$ between them. Blood samples were taken every $5 \mathrm{~min}$, from a cut on the tail tip, for lactate determination. The blood lactate concentration representative of the MLSS was considered at the highest overload in which there was no variation in the blood lactate higher than $1.0 \mathrm{mmol} / \mathrm{L}$ between 10 and 25 min of exercise $[18,19]$

\section{Training Programmes}

The animals were then subjected to a training programme of $60 \mathrm{~min} /$ day, 5 days a week, over 12 weeks. The swimming sessions were run in individual tanks with the established relative overloads according to the rat's weight in order to reach the individual aerobic/anaerobic metabolic transition [18]. Every 30 days, new MLSS tests were conducted to assign new overloads.

\section{Statistics}

Results are presented as means \pm standard deviation and were analyzed using the Students t-test and two-way ANOVA followed by a Newman-Keuls test, where appropriate. Significance level was 5\%.

\section{Results \\ General parameters}

Body weight, food and water intake are illustrated in Table 1. Groups TC $\left[\mathrm{F}_{1,24}=9.33\right], \mathrm{A}\left[\mathrm{F}_{1,24}=11.0\right]$ and TA $\left[\mathrm{F}_{1,24}=\right.$ 11.35] displayed a smaller area under the body weight curve than the controls. Rats in the TA $\left[\mathrm{F}_{1,18}=16.66\right]$ group consumed more food than the sedentary rats in groups $\mathrm{C}$ and $\mathrm{A}$. No difference in water intake was found between the groups.

\section{Prior-to-training evaluations}

The results of the GTT on the 28th day are presented on Figure 1A. Blood serum glucose levels in rats that received alloxan were higher $(\mathrm{A}=1309.0 \pm 337.8, \mathrm{p}<0.05$, student t-test $)$ than those of controls $(C=817.6 \pm 59.6, p<0.05$ student t-test), as reflected by the increase in the area under the serum glucose curves $(\mathrm{mmol} / \mathrm{L} \times 120 \mathrm{~min})$ in this group. There was no difference between the HOMA insulin sensitivity indices of both groups $(\mathrm{C}=22.7 \pm 9.7$ and $\mathrm{A}=17.4 \pm 13.2, \mathrm{p}<0.05$, student $\mathrm{t}$-test $)$ when evaluated on the 28th day (Figure $1 \mathrm{~B}$ ).

On the 28th day, all rats were subjected to the described MLSS protocol. MLSS was performed using overloads of $5.0-7.5 \%$ of the rats' body weights. The animals did not reach the MLSS using the same overloads within the same group. Figure 2 represents the lactate concentration kinetics during exercise for most animals in each group. In the TC group, $25 \%$ of the animals reached the MLSS using overloads of about $5 \%$ of their body weight, and their mean lactate concentration was $7.3 \pm 2.4 \mathrm{mmol} / \mathrm{L}$; the remaining $75 \%$ (Figure 2) reached the MLSS using over-

Table I: Body weight, food intake and water intake.

\begin{tabular}{llll}
\hline Groups & Body Weight & Food intake & Water intake \\
\hline C & $3648.7 \pm 212.4$ & $103.0 \pm 11.0$ & $127.9 \pm 21.2$ \\
TC & $3281.2 \pm 212.0^{\mathrm{a}}$ & $131.3 \pm 8.7$ & $148.6 \pm 22.6$ \\
A & $3258.3 \pm 202.2^{\mathrm{b}}$ & $106.9 \pm 6.5$ & $124.4 \pm 5.2$ \\
TA & $3093.2 \pm 291.2^{\mathrm{c}}$ & $137.6 \pm 19.6^{\mathrm{c}, \mathrm{d}}$ & $156.9 \pm 4.1$ \\
\hline
\end{tabular}

Areas under the body weight (grams $\times 12$ weeks), food intake (food grams $/ 100 \mathrm{~g}$ of body weight $\times 12$ weeks) and water intake (water $\mathrm{ml} /$ $100 \mathrm{~g}$ of body weight $\times 12$ weeks) curves of the animals.

Values are mean \pm standard deviation, $n=8$ animals per group.

$\mathrm{C}=$ Control; $\mathrm{TC}=$ Trained control; $\mathrm{A}=$ Alloxan e $\mathrm{TA}=$ Trained

alloxan $a=C$ vs TC; $b=C$ vs $A ; c=C$ vs TA; $d=A$ vs TA 
A

\section{AREA UNDER GLUCOSE CURVE DURING GTT - 28 DAYS}

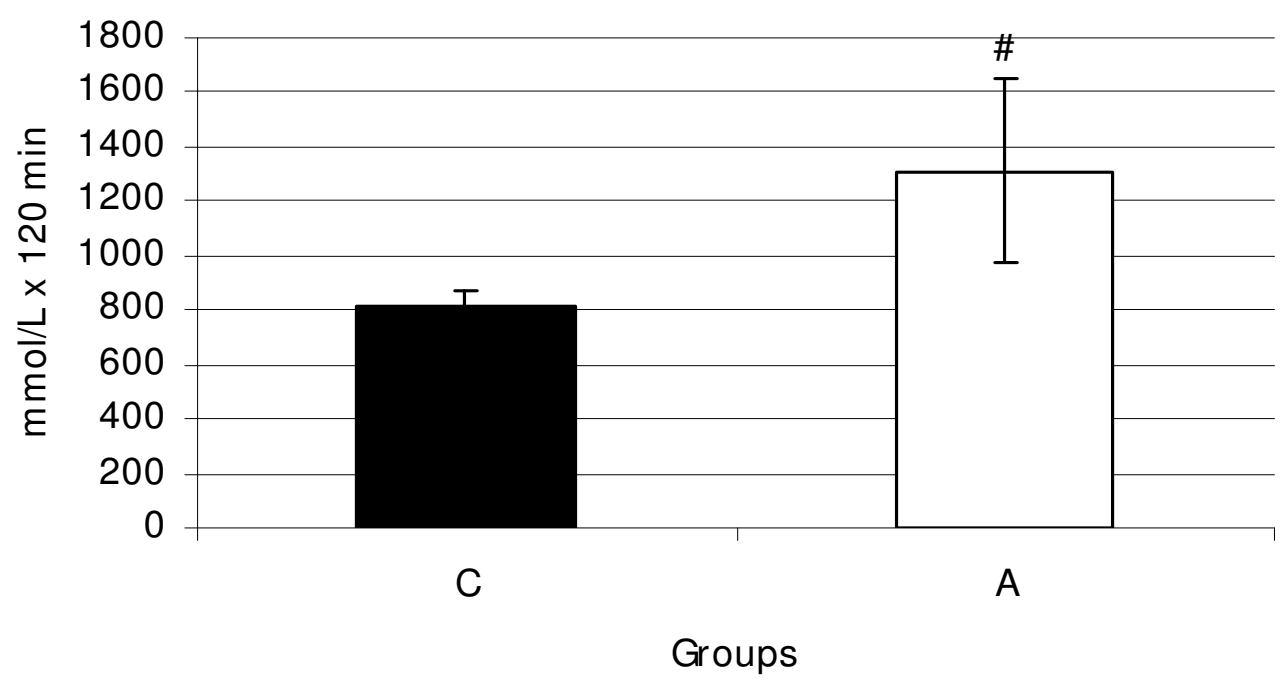

B

\section{HOMA - 28 DAYS}

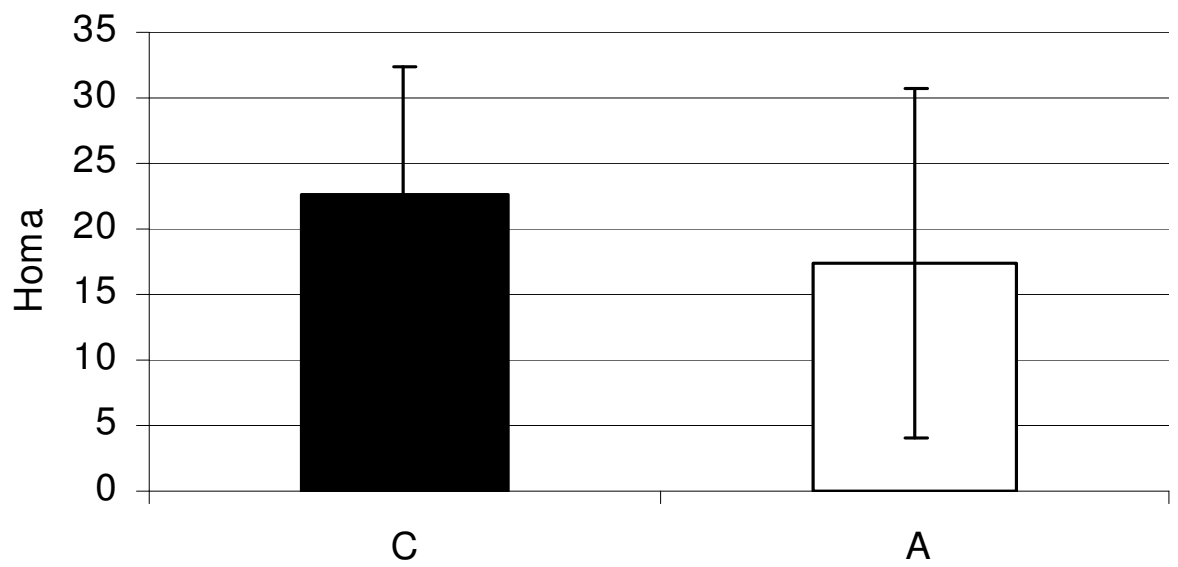

Groups

\section{Figure I}

Area under serum glucose curve during GTT and HOMA - 28 days. A- Area under serum glucose curve during GTT $(\mathrm{mmol} / \mathrm{L} \times 120 \mathrm{~min})$ of the animals after weaning (28 days of age $-\mathrm{C}$ and A). B- HOMA* insulin sensitivity index after weaning ( 28 days of age $-C$ and $A$ ). Values showed as mean \pm standard deviation, $n=8$ animals per group. $C=C o n t r o l ; A=A l l o x a n$. *homeostasis assessment model. \# diference. 


\section{EFFORT TEST - 28 DAYS}

Control
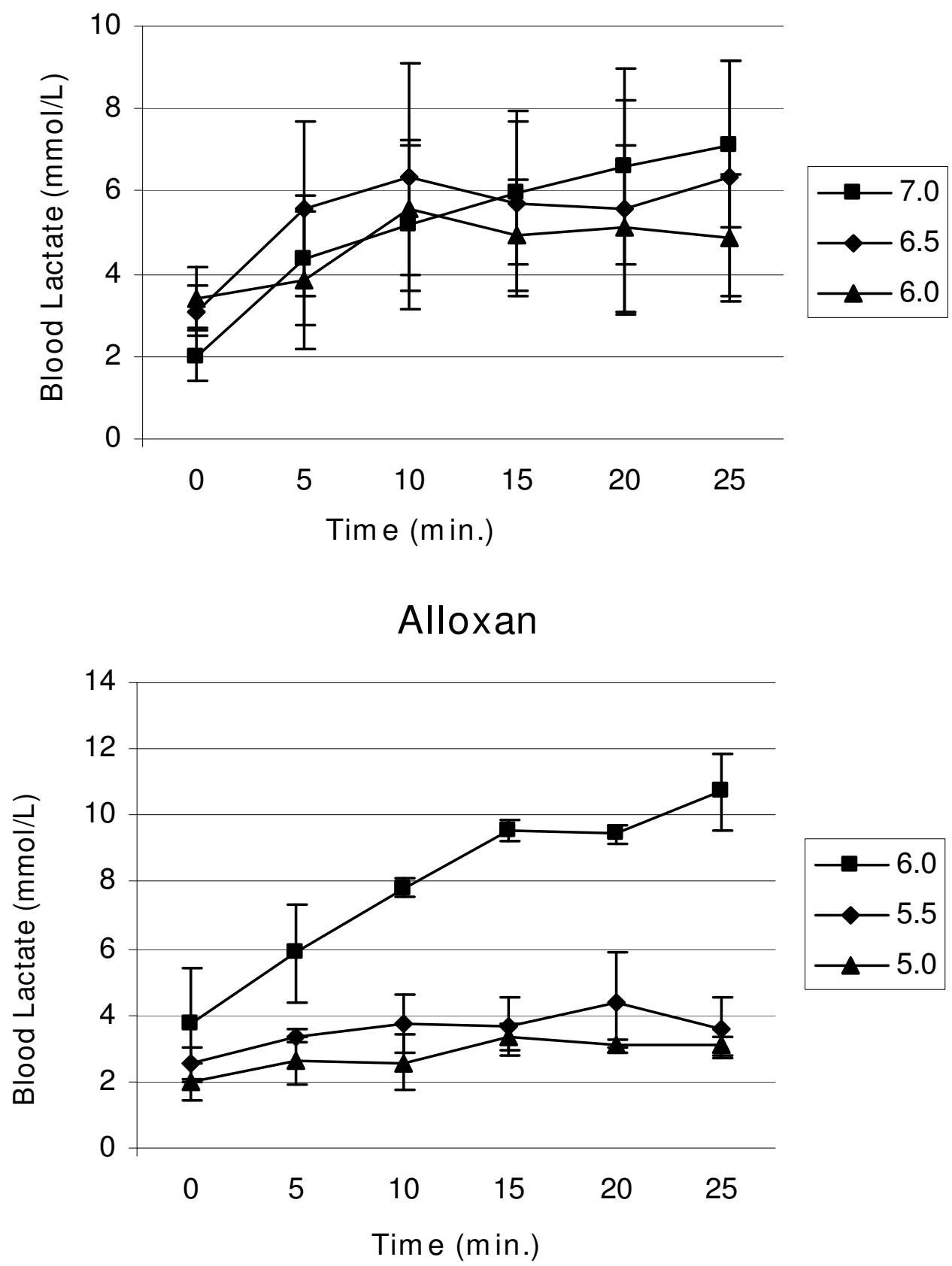

Figure 2

Effort test. Blood lactate concentrations (mmol/L) during the effort tests for determining MLSS of most 28-days-old rats of each group. 
loads of $6.5 \%$ of their body weight and their mean lactate concentration was $6.0 \pm 2.6 \mathrm{mmol} / \mathrm{L}$. In the TA group, $50 \%$ of the animals (Figure 2) reached the MLSS using $5.5 \%$ of body weight overloads and their mean lactate concentration was $3.8 \pm 0.7 \mathrm{mmol} / \mathrm{L}$, while $33.3 \%$ of the animals reached the MLSS with $6.0 \%$ of body weight overloads and their mean lactate concentration was $6.5 \pm 0.6$ $\mathrm{mmol} / \mathrm{L}$, and $16.7 \%$ of the animals reached the MLSS using loads $6.5 \%$ of their body weight, with a mean lactate concentration of $10.4 \pm 0.6 \mathrm{mmol} / \mathrm{L}$.

\section{During training evaluations}

There were no differences between the HOMA indices of the groups at 60 days old $(\mathrm{C}=17.7 \pm 3.6, \mathrm{TC}=19.8 \pm 4.7$; $\mathrm{A}=33.3 \pm 19.6$ and $\mathrm{TA}=32.4 \pm 10.6)$. However, on the $90^{\text {th }}$ day, TC animals were more insulin sensitive than the other groups $\left(\mathrm{TC}=19.8 \pm 2.6\left[\mathrm{~F}_{1,19}=6.96\right] ; \mathrm{C}=28.7 \pm 4.5\right.$; $\mathrm{A}=30.8 \pm 4.8$ and $\mathrm{TA}=31.2 \pm 5.5)$, and on the $120^{\text {th }} \mathrm{day}$, no statistical differences between the groups regarding insulin sensitivity were observed $(\mathrm{C}=19.4 \pm 4.3$; $\mathrm{TC}=$ $17.4 \pm 6.4 ; \mathrm{A}=19.4 \pm 6.4$ and $\mathrm{TA}=18.6 \pm 2.6)$.

At 60 days old, groups A $\left(1043.4 \pm 103.1\left[\mathrm{~F}_{1,26}=61.97\right)\right.$ and TA $\left(1131.2 \pm 189.7\left[\mathrm{~F}_{1,26}=61.97\right]\right)$ showed high serum glucose concentrations based on the area under the serum glucose curve during the GTT, compared with the controls $(\mathrm{C}=774.9 \pm 69.9$ and $\mathrm{TC}=756.9 \pm 38.9)$. On the other hand, at 90 days old $(\mathrm{C}=735.9 \pm 64.1$; $\mathrm{TC}=670.9$ $\pm 40.8 ; \mathrm{A}=1162.9 \pm 202.9$ and $\mathrm{TA}=1017.4 \pm 129.0\left[\mathrm{~F}_{1,26}\right.$ $=5.55])$ and 120 days old $(\mathrm{C}=755.8 \pm 64.5 ; \mathrm{TC}=640.7$ \pm 106.4; $\mathrm{A}=1299.4 \pm 198.3$ and TA 972.2 \pm 135.0$)$ the area under the serum glucose curve in the TA $\left[\mathrm{F}_{1,26}=4.43\right]$ group decreased compared with that in group A (Figure 4).

\section{HOMA}

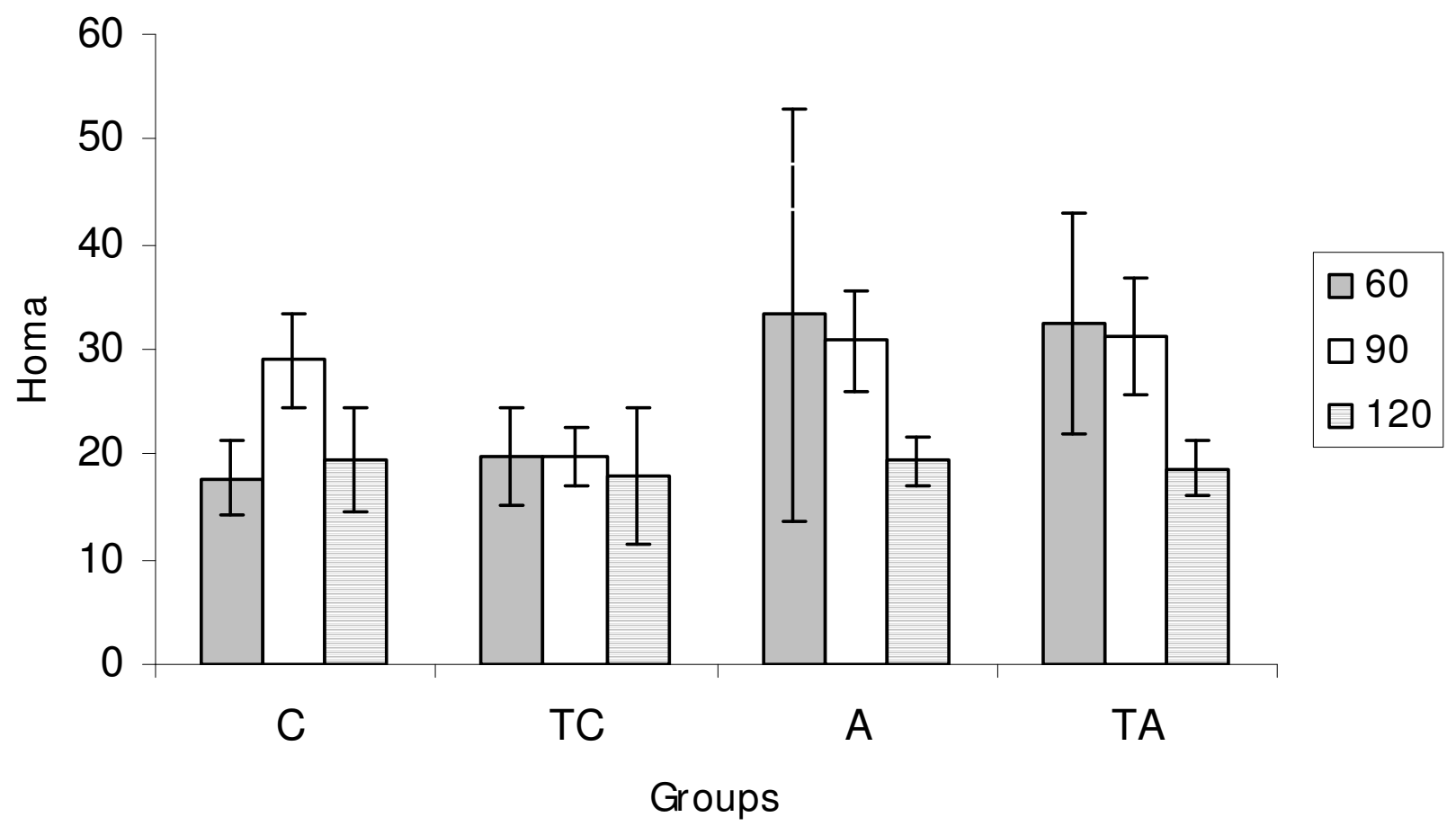

Figure 3

HOMA. HOMA* insulin sensitivity index of 60 th, 90 th and 120 th days of age (C, TC, A and TA). Values showed as mean \pm standard deviation, $\mathrm{n}=8$ animals per group. $\mathrm{C}=$ Control; $\mathrm{TC}=$ Trained control; $\mathrm{A}=\mathrm{Alloxan}$ e TA $=$ Trained alloxan. $\mathrm{a}=\mathrm{C}$ vs TC; e = TC vs TA; *homeostasis assessment model. 


\section{AREA UNDER GLUCOSE CURVE DURING GTT}

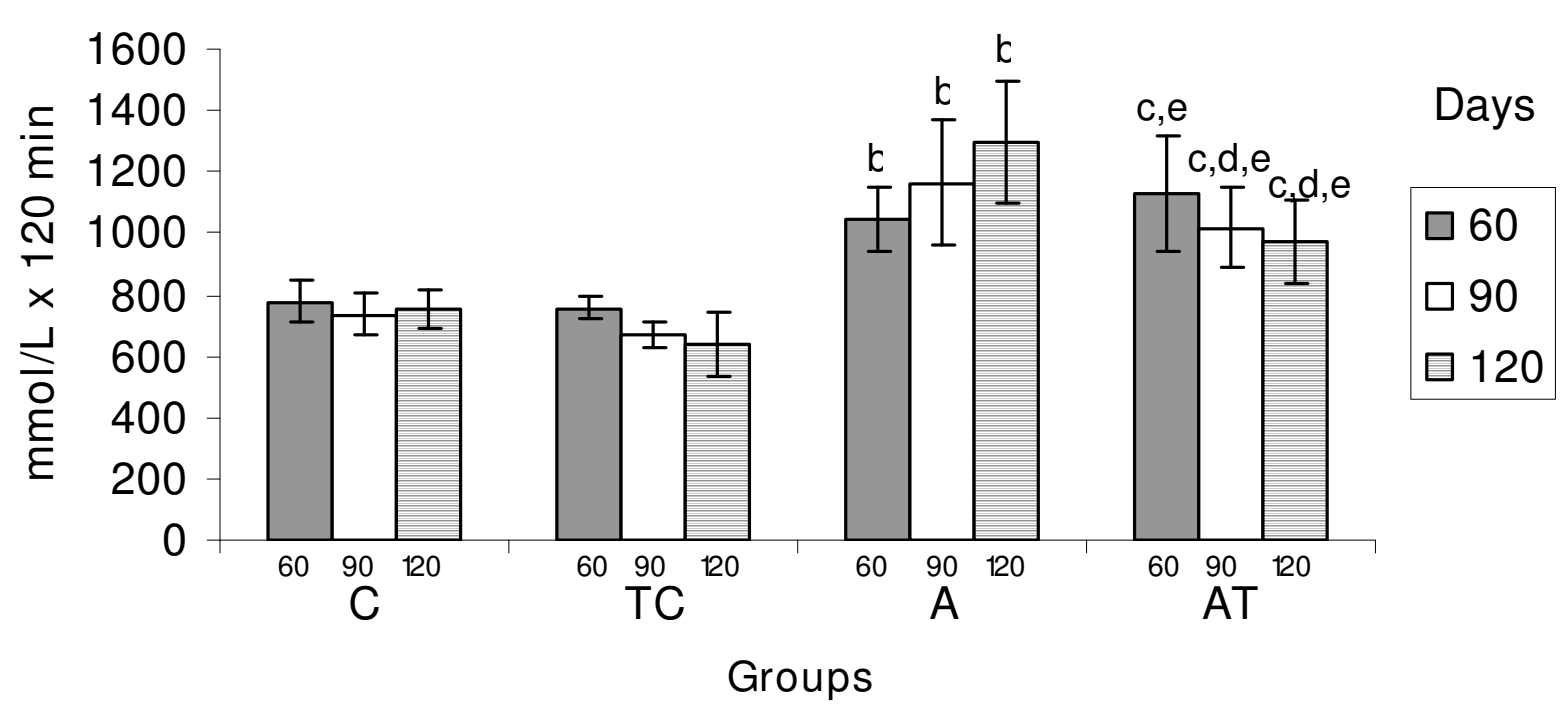

Figure 4

Area under serum glucose curve during GTT. Area under serum glucose curves during GTT (mmol/L $\times 120 \mathrm{~min})$ of 60 th, 90 th and 120 th days of age (C, TC, A and TA). Values showed as mean \pm standard deviation, $n=8$ animals per group. $C$ $=$ Control; $T C=$ Trained control; $A=$ Alloxan e TA $=$ Trained alloxan. $b=C$ vs $A ; c=C$ vs TA; $d=A$ vs TA; e $=$ TC vs TA.

\section{Discussion}

The aim of the present study was to analyze the effects of a physical exercise programme, adjusted to the aerobicanaerobic transition, on the glucose homeostasis of adult Wistar rats treated with alloxan when newly born.

Our results demonstrated that the sedentary group $\mathrm{C}$ showed a greater increase in body weight than did groups A, TA, and TC. Although TA rats had the highest food intake, they did not assimilate this energy as body mass.

It was previously shown that animals receiving streptozotocin in their first days of life had compromised secretory insulin capacity just after drug administration [20]. It is probable that a similar reduction in insulin production took place in this study when the rats were injected with alloxan, because animals in this group demonstrated a low increase in body weight. Reports from other studies have shown that young animals or humans with reduced insulin demonstrated body weight gain impairment and a delay in the process of growth and physical maturation [21].

Obesity is one of the main causes of type 2 diabetes. In the present study, the training programme reduced body weight gain. These results are in agreement with other studies [22] which showed that animals subjected to running sessions gained $24 \%$ less body weight than sedentary controls following 6 weeks of physical training. The literature also states that physical activity on a regular basis and restrictions in body weight gain reduce the incidence of type 2 diabetes in patients with glucose intolerance [23].

The GTT on the 28th day illustrated that the animals exhibited an adequate response to neonatal alloxan administration, via a bigger area under the serum glucose curve than the controls. In the subsequent evaluations at 60,90 and 120 days old, group A rats remained glucose intolerant.

In another study carried out in our laboratory, Oliveira et al (2005) observed that rats receiving alloxan $(200 \mathrm{mg} / \mathrm{kg}$ of body weight) at 2 days old showed spontaneous improvement in glucose tolerance [5]. In the present study, the observed high steady blood serum glucose levels in group A animals was probably due to the later age at which the animals received alloxan ( 6 days) and also because of the higher dosage used ( $250 \mathrm{mg} / \mathrm{kg}$ ). Kodama et al. (1993) showed that when alloxan was administered 
to newly born rats, the earlier the drug was administered the less severe the blood glucose derangement was in later life [4].

According to the American Diabetes Association, patients who present with glucose intolerance and/or altered fasting blood glucose levels are prone to developing type 2 diabetes, and are thus candidates for interventions in order to monitor and control the onset of the disease [24]. The American Diabetes Association also claims that oral glucose tolerance tests and evaluation of fasting blood glucose levels are the best parameters to track the development of type 2 diabetes.

The United Kingdom Prospective Diabetes Study (1995) demonstrated that $\beta$ cell dysfunction in humans starts at around 10-12 years old before type 2 diabetes develops, therefore offering a long interval for the initiation of prophylactic interventions [25]. The non-exercised alloxan rats in the present study remained in this pre-diabetic condition throughout the experiment, illustrating the usefulness of this model in designing intervention strategies in cases of type 2 diabetes in future studies, since there are obstacles to experimentation with humans.

Identification of the MLSS was successfully employed to evaluate the aerobic capacity of the experimental animals [18]. This protocol also enabled the quantification of their individual aerobic capacity. In the present study, the procedures employed to induce glucose intolerance caused a reduction in blood lactate levels in most TA animals at the MLSS compared with controls, even though the overloads during the MLSS were the same for both groups.

Randle, in studies using the hearts and diaphragms of rats suggested the existence of a mechanism known as the glucose-fatty acid cycle. He observed that increases in FFA plasma levels were followed by decreases in glucose uptake and oxidation by these organs [26]. In general, type 2 diabetes leads to an increase in the circulating levels of FFA, which are used up by peripheral tissues, such as the skeletal muscles, saving glycogen [27]. This may have led to reduced glucose utilization, thus resulting in a lower production of lactate in TA rats.

Our results show that when the animals were 90 days old, i.e. 60 days after the start of physical training, the swimming sessions effectively reduced the area under the serum glucose curve of the GTT in TA rats, thus demonstrating a significant recovery in tolerance to glucose (Figure 4). A similar recovery was observed in TA rats at 120 days old. The reduction in serum glucose levels in the TA group could have been mediated by an increase in the numbers of glucose transporters [28]. A previous study conducted in our laboratory demonstrated that swim- ming sessions in the aerobic/anaerobic transition also attenuated glucose intolerance in type 1 diabetes rat models [29].

Knowing the exact moment and how physical activity can contribute to counteracting or preventing type 2 diabetes will be useful in encouraging diabetic patients to take part in physical activity on a regular basis. Page et al. (1992) showed that 6 months of continued regular exercise was not enough time for patients to assimilate this into their life habits [30].

\section{Conclusion}

The neonatal administration of alloxan induced persistent glucose intolerance, which was counteracted by physical training in the aerobic/anaerobic metabolic transition. The use of the HOMA index as an indicator of insulin resistance proved inefficient in detecting differences among the experimental groups in most cases. Thus complementary studies using alternative procedures are necessary in order to obtain a more comprehensive characterization of this model.

\section{Abbreviations}

GTT: Glucose Tolerance Test; MLSS: Maximal Lactate Steady State; HOMA: homeostasis model assessment; FFA: Free fatty acid; IDDM: insulin-dependent diabetes mellitus; NIDDM: non-insulin-dependent diabetes mellitus.

\section{Competing interests}

The authors declare that they have no competing interests.

\section{Authors' contributions}

CSAM, conceived of the study, developed the study proto$\mathrm{col}$, reviewed the references, abstracted data, analyzed the data, and wrote the paper. CR, GGA, MBA, FBM-G, CAMO, FAV and EL, participated in the design of the study, reviewed the manuscript, collaborated in the biochemical dosages, and advised on revisions to the manuscript. MARM. conceived of the study, gave financial support and participated in its design and coordination and helped to draft the manuscript. All authors read and approved the final manuscript.

\section{Acknowledgements}

The authors wish to thank Clarice Y. Sibuya, Eduardo Custódio and José Roberto R. Silva for technical assistance. This research is supported by Brazilian foundation FAPESP (process n. 06/5I213-0 and 05/57741-6) and CNPq (process n. 133016/2006-4).

\section{References}

I. Powers SK, Howley ET: Exercise physiology - theory and applications to fitness and performance McGraw-Hill Companies; 2004.

2. Mello MAR, Luciano E: Obesidade e desnutrição. Obesidade Ist edition. 2003, I:153-169. 
3. Portha B, Blondel O, Serradas P, McEvoy R, Giroix MH, Kergoat M, Bailbe $D$ : The rats models of non-insulin-dependent diabetes induced by neonatal strptozotocin. Diabete Metab 1989, 15:6I-75.

4. Kodama T, Iwase M, Nunoi K, Maki Y, Yoshinari M, Fujishima M: A new diabetes model induce by neonatal alloxan treatment in rats. Diabetes Res Clin Pract 1993, 20:183-189.

5. Oliveira CAM, Luciano E, Mello MAR: The role of exercise on long term effects of alloxan administered in neonatal rats. Exp Physiol 2004, 90:79-86.

6. Schneider SH, Ruderman NB: Exercise and NIDDM (technical review). Diabetes Care 1990, 13:785-9.

7. Castaneda C: Type 2 diabetes mellitus and exercise. Nutr Clin Care 200I, 3:349-58.

8. Castaneda C, Layne LE, Orians LM, Gordon PL, Walsmith J, Foldvari $M$, Roubenoff R, Tucker KL, Nelson ME: A randomized controlled trial of resistance exercise training to improve glycemic control in older adults with type 2 diabetes. Diabetes Care 2002, 25:2335-4I.

9. Eriksson KF, Lindgärde F: Prevention of type 2 (non-insulindependent) diabetes mellitus by diet and physical exercise: the 6-year Malmo feasibility study. Diabetologia 1991, 34:891-898.

10. Reeves PG, Nielsen FH, Fahey Jr GC: AIN-93 Purified diets for laboratory rodents: Final report of the American Institute of Nutrition Ad Hoc Writing Committee on the Reformulation of the Ain-76A Rodent Diet. J Nutr 1993, I 23(II): I939- I95I.

II. Herbert V, Lau KS, Gotlied CW, Bleicher ST: Coated Charcoals immunoassay of insulin. J Clin Endocrinol Metab 1965, 25: I375-84.

12. Matthews JN, Altman DG, Campbell MJ, Royston P: Analysis of serial measurements in medical research. BMJ 1990, 300(67|9):230-235.

13. Bonora E, Targher G, Alberiche M, Bonadonna RC, Saggiani F, Zere MB, Monauni T, Muggeo M: Homeostasis model assessment closely minors the glucose clamp techinique in the assessment of insulin sensitivy: studies in subjects eith various degrees of glucose tolerance and insulin sensitivy. Diabetes Care 2000, 23:57-63.

14. Heck H, Mader A, Hess G, Mucke S, Muller R, Hollmann W: Justification of the 4-mmol/l lactate threshold. Int J Sports Med 1985, 6:117-30.

15. Beneke R, Leithäuser RM, Hütler M: Dependence of the maximal lactate steady state on the motor pattern of exercise. $\mathrm{Br} J$ Sports Méd 2001, 35:192-196.

16. Contarteze RV, Manchado FD, Gobatto CA, De Mello MA: Stress biomarkers in rats submitted to swimming and treadmill running exercises. Comp Biochem Physiol A Mol Integr Physiol 2007 in press.

17. Ferreira JC, Rolim NP, Bartholomeu JB, Gobatto CA, Kokubun E, Brum PC: Maximal lactate steady state in running mice: effect of exercise training. Clin Exp Pharmacol Physiol 2007, 34:760-5.

18. Gobatto CA, Mello MAR, Sibuya CY, Azevedo JR, Santos LA, Kokubun E: Maximal lactate stedy state in rats submitted to swimming exercise. Comparative Biochemistry and Physiology 200I, 130:2I-27.

19. Beneke R: Methodological aspects of maximal lactate steady state-implications for performance testing. Eur J Appl Physiol 2003, 89:95-9.

20. Leduque P, Aratan-Spire S, Wolf B, Dubois PM, Czernichow P: Localization of thyrotropin-releasing hormone- and insulin-immunoreactivity in the pancreas of neonatal rats after injection of streptozotocin at birth. Cell Tissue Res 1987, 248:89-94.

21. Luciano E, Carneiro EM, Reis MAB, Peres B, Velloso LA, Boschero $A C$, Saad MJA: Endurance training modulates early steps of insulin signaling in rat muscle. Medicine and Science in Sports and Exercise 1998, 30:S24.

22. Levin BE, Dunn-Meynell AA: Chronic exercise lowers the defended body weight gain and adiposity in diet-induced obese rats. Am J Physiol Regul Integr Comp Physiol 2004, 286:R77I-8.

23. Sigal RJ, Kenny GP, Wasserman DH, Castaneda-Sceppa C, White RD: Physical activity/exercise and type 2 diabetes. A consensus statement from the American Diabetes Association. Diabetes Care 2006, 29:1433-1438.

24. American Diabetes Association: ADA stand position: physical activity/exercise and diabetes mellitus. Diabetes Care 2003, 26:573-7.
25. United Kingdom Prospective Diabetes Study (UKPS): 13: Relative efficacy of randomly allocated diet, sulphonylurea, insulin, or metformin in patients with newly diagnosed non-insulin dependent diabetes followed for three years. BM] 1995 , 310:83-8.

26. Randle PJ, Kerbey AL, Espinal J: Mechanisms decreasing glucose oxidation in diabetes and starvation: role of lipid fuels and hormones. Diabetes Metab Rev 1988, 4:623-38.

27. Lupi R, Dotta F, Marselli L, Del Guerra S, Masini M, Santangelo C Patane G, Boggi U, Piro S, Anello M, Bergamini E, Mosca F, Di Mario $U$, Del Prato S, Marchetti P: Prolonged exposure to free fatty acids has cytostatic and pro-apoptotic effects on human pancreatic islets: evidence that $\beta$-cell death is caspase mediated, partially dependent on ceramide pathway, and $\mathrm{Bcl}-2$ regulated. Diabetes 2002, 5 I: | 1437-I442.

28. Lee JS, Bruce CR, Tunstall RJ, Cameron-Smith D, Hügel H, Hawley A: Interaction of exercise and diet on glut-4 protein and gene expression in type I and type II rat skeletal muscle. Acta Physiol Scand 2002, 175:37-44.

29. Oliveira CAM, Luciano E, Marcondes MCCG, Mello MAR: Effects of swimming training at the intensity equivalent to aerobicl anaerobic metabolic transition in alloxan diabetic rats. Journal of Diabetes Complications 2007, $21: 258-264$.

30. Page RCL, Harnden KE, Cook JTE, Turner RC: Can life-styles of subjects with impaired glucose tolerance be changed? A feasibility study. Diabet Med 1992, 9:562-566.

\section{Pre-publication history}

The pre-publication history for this paper can be accessed here:

http://www.biomedcentral.com/1472-6823/8/11/prepub
Publish with Bio Med Central and every scientist can read your work free of charge

"BioMed Central will be the most significant development for disseminating the results of biomedical research in our lifetime. "

Sir Paul Nurse, Cancer Research UK

Your research papers will be:

- available free of charge to the entire biomedical community

- peer reviewed and published immediately upon acceptance

- cited in PubMed and archived on PubMed Central

- yours - you keep the copyright
BioMedcentral 